\title{
MOTIVES FOR THE USE OF COMPETITIVE DIALOGUE
}

\author{
Paulos Abebe Wondimu ${ }^{1}$, Jardar Lohne ${ }^{2}$ and Ola Lædre ${ }^{3}$
}

\begin{abstract}
Competitive dialogue (CD) is a seldom-practised procurement procedure in Norway. The Norwegian Public Roads Administration (NPRA) plans to use it in complex and mega infrastructure project in the future. This study investigates how $\mathrm{CD}$ has contributed to the implementation of lean in the public sector by answering the following two research questions: What are the motives for using CD?; and How was the CD carried out (timeline, main activities etc.)?

With a supporting literature study, four cases were studied by conducting a document study and semi-structured in-depth interviewees with eight key informants. Several motives why CD has been used in the target projects were identified. However, none the identified motives were to directly implement lean. Furthermore, eleven major activities of CD and two project implementation models that have used $\mathrm{CD}$ were identified in the case projects. The motives behind implementing CD are found to be comparable to the motives for implementing lean construction principles. In addition, the dialogue phase is found to be at the core of the process and could contribute to reducing significant waste. The findings provide a contribution of how $\mathrm{CD}$ can be used to implement lean in public procurement.
\end{abstract}

Keywords: Lean, Competitive dialogue, CD, Early contractor involvement, ECI public procurement, waste.

\section{INTRODUCTION}

Based on the literature study leading to this paper, competitive dialogue (CD) seems to be little known outside the context of certain EU countries (Haugbølle et al. 2015). CD was introduced in 2004 by the European parliament for particularly complex contracts. This procurement procedure allows public clients to hold discussions with shortlisted contractors regarding the client's requirements before the contractors submit their tenders (European Parliament 2014). The purpose of introducing CD is to give public owners a flexible procurement procedure that enables a dialogue concerning all aspects of the contract with several competitors (Telles and Butler 2014). CD is one of the approaches for early contractor involvement (ECI) and is a procurement procedure that is recognised by EU public procurement law (Wondimu et al. 2016).

Lean thinking is establishing a system that constantly explores ways to reduce waste. Furthermore, it is getting more attention as a way to reduce the costs associated with government procurement (Waterman and McCue 2012). When the Lean Project Delivery

$1 \quad$ PhD Candidate, Department of civil and environmental engineering (IBM), Norwegian University of Science and Technology (NTNU), Trondheim, Norway/Senior Engineer, Norwegian Public Roads Administration (NPRA), Norway, +4790111814, paulos.wondimu@ntnu.no/ paulos.wondimu@vegvesen.no

Researcher, Dr.Art., IBM, NTNU, jardar.lohne@ntnu.no

Assoc. prof., Dr.Ing., IBM, NTNU, ola.ladre@ntnu.no 
System is used in the construction sector, it is expected that the contractor's job is not only to provide what the client wants but also to first help the client decide what they want. Subsequently, the purpose of the client and constraints should be understood by the contractors (Ballard 2008).

Finland has begun experimenting with adapting lean ideology into their public alliance projects based on $\mathrm{CD}$. Other countries in the EU have already established a working system based on lean (Petäjäniemi and Lahdenperä 2012). However, CD is a relatively new and very little practised procurement method in Norway. So far, empirical research on CD in public infrastructure projects is limited. In particular attention on how competitive dialogue can contribute to implementing lean. Therefore, this paper intends to explore Norwegian experiences by addressing the following research questions:

- What are the key motives for using competitive dialogue (CD)?

- How was the competitive dialogue (CD) carried out (main activities, timeline etc.)?

The Norwegian Public Roads Administration (NPRA) has so far used CD in six projects. This paper presents empirical data - collected from the client side - from four of these six projects. The four infrastructure projects presented in Table 1 were chosen while the two remaining projects were omitted from this study because they were a ferry procurement and a project concept development, respectively. Since three of the four investigated projects were not finished at the time of this study, it was not possible to see the long-term effects of the CD.

Table 1: Presenting the cases

\begin{tabular}{|c|c|c|c|c|}
\hline & Case 1 & Case 2 & Case 3 & Case 4 \\
\hline Project title & $\begin{array}{l}\text { E6 Trondheim- } \\
\text { Stjørdal }\end{array}$ & $\begin{array}{l}\text { E6 Helgeland } \\
\text { North }\end{array}$ & $\begin{array}{c}\text { Fv32 } \\
\text { Lilleelvkrysset }\end{array}$ & $\begin{array}{l}\text { E6 Helgeland } \\
\text { South }\end{array}$ \\
\hline Project type & $\begin{array}{l}0.6 \mathrm{~km} \text { road in } \\
\text { clay (densely } \\
\text { populated area) }\end{array}$ & $\begin{array}{l}62 \mathrm{~km} \text { new road } \\
\text { (scarcely } \\
\text { populated area) }\end{array}$ & $\begin{array}{l}0.515 \mathrm{~km} \text { new } \\
\text { tunnel (densely } \\
\text { populated area) }\end{array}$ & $\begin{array}{c}58 \mathrm{~km} \text { new road } \\
\text { (scarcely } \\
\text { populated area) }\end{array}$ \\
\hline $\begin{array}{l}\text { Contractual } \\
\text { agreement }\end{array}$ & $\begin{array}{l}\text { Design and } \\
\text { Build }\end{array}$ & $\begin{array}{l}\text { Design, Build and } \\
\text { Operate }\end{array}$ & Design and Build & $\begin{array}{l}\text { Design, Build } \\
\text { and Operate }\end{array}$ \\
\hline Project start year & 2009 & 2015 & 2015 & 2017 \\
\hline
\end{tabular}

\section{RESEARCH METHODOLOGY}

In order to address the research questions, a literature study, eight interviews with key actors from the selected cases and a document study of the chosen cases presented in Table 1 were carried out. The methodological approaches described by Yin (2013) was used during the case studies. The literature study concentrated on research databases, library databases and references in relevant articles was carried out to establish a theoretical framework.

Semi-structured in-depth interviews with eight key personnel involved in the CD process were conducted. Each interview was carried out face-to-face, based on an interview guide and lasted between one and two hours. All the interviewees were recorded and later transcribed. Six of the interviewees have held a construction manager or a project manager position in the case projects. The remaining two interviewees were 
representatives from the NPRA head office (Vegdirektoratet) who participated in the dialogue phase. The document study consisted of documents received from interviewees, such as contract documents and dialogue invitation documents. The document study was carried out in order to find background information about the cases and how CD is carried out in NPRA. Data triangulation was achieved through different sources of data (interviews and document study).

\section{THEORETICAL BACKGROUND}

\subsection{Lean and public procurement}

Lean thinking is not simply adopting a lean tool (Waterman and McCue 2012). Instead, it involves implementing various measures in construction management to remove waste (Song and Liang 2011). Lean is a philosophy that constantly looks to reduce waste and increase customer satisfaction that can be ingrained in a system (Waterman and McCue 2012). Furthermore, it aims to achieve the intended time, cost and quality simultaneously (Tommelein 2015).

Public procurement involves the spending of public money and has impacts on innovation (Uyarra and Flanagan 2010). It is subjected to accountability and detailed procedures since it is exposed to a high risk of fraud and corruption (Erridge and Nondi 1994). The primary consideration of every government should be the efficiency of the procurement process as public resources have become scarce (Waterman and McCue 2012). According to this literature, there seems to be a potential for applying lean thinking to public procurement.

The separation between design and construction in public procurement is generally considered to be inefficient. Principally, the lean philosophy promotes an integration of design and construction (Jørgensen and Emmitt 2009) to reduce waste in construction (Song and Liang 2011). ECI is one of the basic principles of lean to achieve integration between the design team and the construction team (Gil et al. 2000).

When lean thinking is applied in public procurement, it is possible to analyse the current processes for value as well as to identify obvious waste in the process. Furthermore, based on lean thinking it is possible to develop a set of tools and documents to support a standardised process (Waterman and McCue 2012).

\subsection{Competitive Dialogue (CD)}

$\mathrm{CD}$ is explicitly aimed for complex projects which require the development of the best solution to address specific client needs. It is a flexible procedure that secures competition and dialogue (Albano and Sparro 2010). In this process, the client can discuss all aspects of the project with the shortlisted contractors (Uttam and Le Lann Roos 2014). It gives the contracting parties the opportunity to discuss, among other things, sustainability and renewable energy objectives, and the client can ensure its long-term commitments are taken into account (O'Brien and Hope 2010).

$\mathrm{CD}$ can be related to other public procurement procedures, as for example the negotiated procedure (Nagelkerke et al. 2008). In the negotiated procedure, direct discussions take place between the owner and one or more contractors of the owner's choice (Erridge and Nondi 1994). On the other hand, it is different from the negotiations procedure because in $\mathrm{CD}$ the negotiations are concentrated within a particular phase in the procurement process (European Commission 2006). 
CD's largest disadvantage is its relatively high transaction costs (Siemonsma et al. 2012). The process is time-consuming and labour-intensive for both the client and contractors. The client should conduct several dialogues to select the qualified contractor and should document the dialogues for the sake of transparency. The contractors should prepare detailed documentation after each dialogue, which costs a lot as well (Hoezen and Hillig 2008).

\section{FINDINGS AND DISCUSSION}

\subsection{What are the key motives for using CD?}

The key motives for using CD, which were raised by the interviewees, are presented in the following section. Case 1 is comparable with case 3 , and case 2 is comparable with case 4. Therefore, the findings are presented according to the above in the following section.

Regarding case 1 and 3, project complexity (technical difficulty) was the major motive for using CD in these projects. These projects were defined as complex among other things due to sensitive ground conditions (quick clay) and the surrounding environment (since the project was in an urban area). For such a kind of complexity, the client lacked experience and reference projects from similar project challenges. This leads to difficulty in the design and execution of the projects. It was also difficult to estimate the projects' costs. Besides the projects' complexity, case 1 was the first infrastructure project where the NPRA used CD. Hence, it was used as a pilot project to try the procedure.

Regarding case 2 and 4, the motives of using CD in this project were to identify and determine how the client's requirements and needs could best be met. Furthermore, the other motives were to create a platform for the client and the individual suppliers to work together to find solutions that best meet client's needs. The projects' complexity was also the motive to use CD in these two case projects. The projects were defined as complex by taking into consideration the length of the road project (approx. 60KM) and the contract complexity (the contract includes design, construction, operation and maintenance of the road project for 15 years). In addition, the wish to try a new type of contract that can decrease the current conflict level and the problems of the traditional project delivery methods was another motive. To reduce the project risk level during the dialogue phase was also another reason to use CD. The client's need for better solutions constituted the motive for ECI.

According to the findings, project complexity was not the only reason for the use of CD. Besides that, NPRA wanted to achieve other goals as well, such as innovation, low level of conflict, etc. However, the interviewees did not raise any direct motives that were related to lean. Therefore, the underlying motives of implementing CD in the case projects were not to implement lean. However, the key motives for using CD resemble, to a large degree, the motives of lean construction. Some of the CD motives that resemble the motives of lean construction are overcoming project complexity, creating a common platform, identifying how the client's needs can best be fulfilled, reducing the risk level, ECI and obtaining innovative solutions.

\subsection{How was the CD carried out?}

Eleven main activities used during CD were identified from the case projects. The main activities are showed in Table 2. The first three activities concern preparation phases of the client. The client uses the first two activities to prepare a draft tender document and to plan the dialogue. The third activity is used to evaluate if there is enough capacity in 
the supplier market for the project. During the dialogue, the client, together with the contractors, develops the draft tender document. Then they hand out the final tender document together with the invitation to competitive tender. The contractor uses the final tender document during submission of a tender.

Table 2: Main activities in CD before the awarding of the contract (developed based on documents from case projects)

\begin{tabular}{|c|c|c|}
\hline Activities & Milestones & $\begin{array}{l}\text { Contractor } \\
\text { Involvement }\end{array}$ \\
\hline Preparation of tender document & & Before \\
\hline Preparation of plan for dialogue & & $\begin{array}{l}\text { contractor } \\
\text { involvement }\end{array}$ \\
\hline \multicolumn{3}{|l|}{$\begin{array}{l}\text { Assessing and communication with the } \\
\text { supplier market }\end{array}$} \\
\hline $\begin{array}{l}\text { Contractors preparation of } \\
\text { prequalification document }\end{array}$ & $\begin{array}{l}\text { Announcing the project and } \\
\text { invitation to participate }\end{array}$ & \multirow{2}{*}{$\begin{array}{l}\text { Any contractor } \\
\text { who applied to } \\
\text { be considered }\end{array}$} \\
\hline Prequalification & $\begin{array}{c}\text { Submission of prequalification } \\
\text { document }\end{array}$ & \\
\hline Handout of the draft tender document & $\begin{array}{l}\text { Invitation to participants to } \\
\text { dialogue }\end{array}$ & $\begin{array}{l}\text { Shortlisted } \\
\text { contractors }\end{array}$ \\
\hline \multicolumn{3}{|l|}{ Contractors develop proposals } \\
\hline Dialogue & Submission of the proposals & \\
\hline Handout of the final tender document & Invitation to competitive tender & \\
\hline \multicolumn{3}{|l|}{ Contractors preparation of bid } \\
\hline \multirow[t]{2}{*}{ Owner control the submitted tenders } & Submission of tender & \\
\hline & Contract signing & One contractor \\
\hline
\end{tabular}

Regarding the timeline, the timing of when CD was used in the case projects is described based on two major project implementation models that were used together with CD in the case projects. These two models are illustrated in Figure 1 as model 2 and 3. Model 2 \& 3 illustrate the two approaches that CD was used together with a DB contract in the case projects. Model 2 was used in case 1 and 3, whereas model 3 was used in case 2 and 4. The arrows in models 1-3 illustrate when the dialogue has happened and when the DB contractor took over the project.

The first model, model 1 , is based on a design-build DB contract and does not have a dialogue phase. However, it is presented in Figure 1 in order to be used as a reference to explain the other two models that have a dialogue phase. Furthermore, it is to illustrate that a DB contract can happen at various times in a project. 


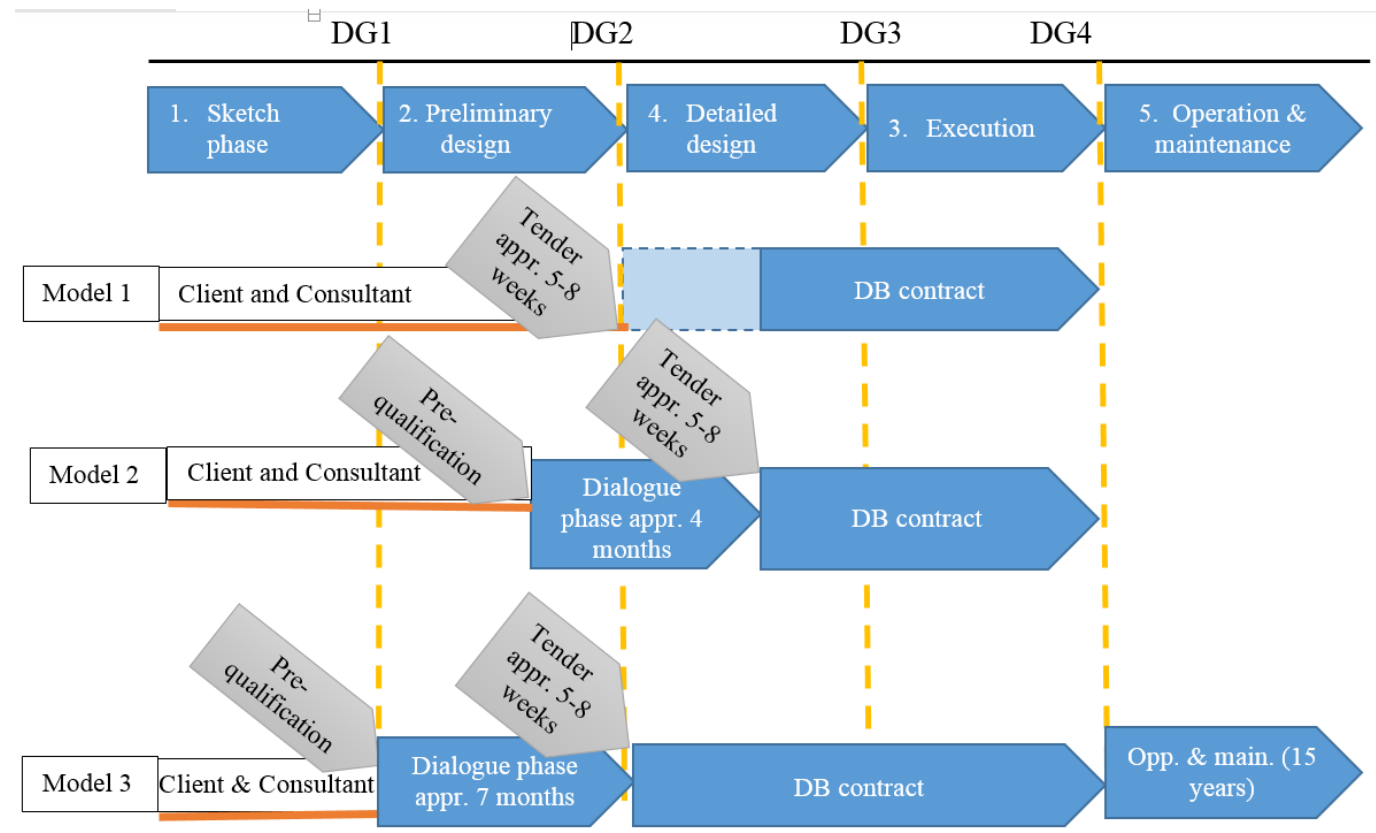

Figure 1: Project implementation models (developed based on documents from Helgeland projects). DG denotes decision gates. DB denotes design-build contract.

Model 2 was used when the client had several technical alternatives to solve the project challenges but when they were not sure which of the alternatives would be the cheapest to fulfil all their requirements. In this model, the contractors have the possibility to influence how to execute the project. Thus, it is possible to conclude that model 3 was used for technically complex projects.

Model 3 was used for large and complex projects. The complexity of these projects was not limited to the technical level, how to execute it like in the case of model 2, but also in the options of what and where to build. One of the goals of model 3 was that design, construction and operation shall be considered together in order to provide savings and other advantages.

Model 2 and model 3 have a dissimilar length of dialogue phase. The length of the dialogue phase can vary depending on the project's need. Furthermore, the dialogue can take place at different phases of a project. In model 2, the dialogue phase takes place between the preliminary design and the detail design phases. In model 3, the dialogue starts in an earlier phase compared to model 2. It takes place during the preliminary design phase. In addition, in model 3 , the contractor has responsibility for the operation and maintenance of the road for 15 years, which is not the case in model 2.

Of the above eleven main activities of $\mathrm{CD}$, the dialogue phase is at the core of the process. It is an important stage to reduce significant waste. This can happen in several ways. The first way is as the contractor gets the possibility to develop the tender document together with the client. The second one is that both the client and the contractor are involved in the development of the project in this phase. The third way is that the client gets support from the contractors in deciding what to build. The fourth way is that individual goals can be aligned to the project goals during the dialogue stage. All this contributes to reducing waste in the project execution phase. Therefore, the dialogue phase in $\mathrm{CD}$ can contribute to implementing lean in public infrastructure projects. 


\section{CONCLUSIONS}

This paper has addressed how competitive dialogue can contribute to implementing lean by studying four infrastructure projects in Norway. The key motives for using CD and how it was carried out was the focus of the study.

Project complexity is the requirement from the EU public procurement directive to justify the use of CD. The findings show that, in the studied cases, the owner has had several reasons beyond that to use $\mathrm{CD}$. However, none of the reasons given by the interviewees shows that the direct motive of implementing CD in the studied cases was to implement lean or to remove waste. This might be due to the fact that personnel involved in the CD practising are not lean experts. Thus, it is possible to conclude that the NPRA's primary focus during the use of $\mathrm{CD}$ in the case projects was not to implement lean.

However, the key motives for using CD resemble, to a large degree, the motives of lean construction. Some of the $\mathrm{CD}$ motives that resemble the motives of lean construction are overcoming project complexity, creating a common platform, identifying how the client's needs can best be fulfilled, reducing the risk level, ECI and obtaining innovative solutions.

Regarding how CD was carried out, eleven main activities of CD and two project implementation models were identified from the case projects. The studied cases have used model 2 and model 3, which have different timings of implementing CD. This study has found that the dialogue phase is at the core of the CD process. Public owners could use it to reduce waste as it promotes integration between the client and the contractor in several ways. Furthermore, the dialogue phase could also be used to better align the motives of $\mathrm{CD}$ with the motives of lean.

In the future, the long-term effect of CD could be studied in order to explore how the procedure affects the operation and maintenance phase of projects. In addition, other types of projects than just infrastructure projects could also be studied to cross-reference the experience.

\section{REFERENCES}

Albano, G. L., and Sparro, M. (2010). "Flexible strategies for centralized public procurement." Review of Economics and Institutions, 1(2).

Ballard, G. (2008). "The lean project delivery system: An update." Lean Construction Journal, 1-19.

Erridge, A., and Nondi, R. (1994). "Public procurement, competition and partnership." European Journal of Purchasing \& Supply Management, 1(3), 169-179.

European Commission, P. P. P. (2006). "Explanatory Note-Competitive Dialogue-Classic Directive." Directorate General Internal Market and Services.

European Parliament, C. o. t. E. U. (2014). "Directive 2014/24/EU of the European Parliament and of the Council of 26 February 2014 on public procurement and repealing Directive 2004/18/EC Text with EEA relevance." Official journal of the European Union.

Gil, N., Tommelein, D., Kirkendall, B., and Ballard, G. "Lean product-process development process to support contractor involvement during design." Proc., Computing in Civil and Building Engineering, ASCE, 1086-1093.

Haugbølle, K., Pihl, D., and Gottlieb, S. C. (2015). "Competitive Dialogue: Driving Innovation Through Procurement?" Procedia Economics and Finance, 21, 555-562. 
Hoezen, M., and Hillig, J.-B. "The Competitive Dialogue Procedure: Advantages, Disadvantages, and its Implementation into English and Dutch Law." Proc., Proceedings COBRA RICS Construction and Building Research Conference., 09.

Jørgensen, B., and Emmitt, S. (2009). "Investigating the integration of design and construction from a "lean" perspective." Construction Innovation, 9(2), 225-240.

Nagelkerke, M., Van Rijn, M., Huith, G., and Van Valkenburg, M. "Competitive Dialogue: Abyss or Opportunity?" Proc., 3rd International Public Procurement Conference Proceedings, 275-294.

O'Brien, G., and Hope, A. (2010). "Localism and energy: Negotiating approaches to embedding resilience in energy systems." Energy Policy, 38(12), 7550-7558.

Petäjäniemi, P., and Lahdenperä, P. "Alliance contracting-one for all and all for one (Finland)." Proc., European Infrastructure Procurement Symposium, Conflict between Institutional Frameworks and Managerial Project Practice. Copenhagen, Danimarca, 12-15.

Siemonsma, H., Van Nus, W., and Uyttendaele, P. (2012). "Awarding of Port PPP contracts: the added value of a competitive dialogue procedure." The flagship journal of international shipping and port research, 39(1), 63-78.

Song, L., and Liang, D. (2011). "Lean construction implementation and its implication on sustainability: a contractor's case study." Canadian Journal of Civil Engineering, 38(3), 350-359.

Telles, P., and Butler, L. (2014). "Public Procurement Award Procedures in Directive 2014/24/EU." Novelties in the 2014 Directive on Public Procurement, Djof Publishing.

Tommelein, I. D. (2015). "Journey toward lean construction: Pursuing a paradigm shift in the AEC Industry." Journal of Construction Engineering and Management, 141(6), 04015005.

Uttam, K., and Le Lann Roos, C. (2014). "Competitive dialogue procedure for sustainable public procurement." Journal of Cleaner Production.

Uyarra, E., and Flanagan, K. (2010). "Understanding the innovation impacts of public procurement." European Planning Studies, 18(1), 123-143.

Waterman, J., and McCue, C. (2012). "Lean thinking within public sector purchasing department: the case of the UK public service." Journal of Public Procurement, 12(4), 505.

Wondimu, P. A., Hosseini, A., Lohne, J., Hailemichael, E., and Lædre, O. "Early Contractor Involvement in Public Infrastructure Projects." Proc., Proc. 24th Ann. Conf. of the Int'l. Group for Lean Construction, sect.3 pp. 13-22.

Yin, R. K. (2013). Case study research: Design and methods, Sage publications. 